\title{
Long-Term Changes of Aquatic Invasive Plants and Implications for Future Distribution: A Case Study Using a Tank Cascade System in Sri Lanka
}

\author{
Champika S. Kariyawasam ${ }^{1,2, *(\mathbb{D})}$, Lalit Kumar ${ }^{1}\left(\mathbb{D}\right.$, Benjamin Kipkemboi Kogo ${ }^{1} \mathbb{D}$ and Sujith S. Ratnayake ${ }^{1,2}$ \\ 1 Ecosystem Management, School of Environmental and Rural Science, University of New England, \\ Armidale, NSW 2351, Australia; lkumar@une.edu.au (L.K.); bkogo@myune.edu.au (B.K.K.); \\ rratnay2@myune.edu.au (S.S.R.) \\ 2 Ministry of Environment and Wildlife Resources, Battaramulla 10120, Sri Lanka \\ * Correspondence: ckariyaw@myune.edu.au; Tel.: +61-421-077-454
}

check for updates

Citation: Kariyawasam, C.S.; Kumar,

L.; Kogo, B.K.; Ratnayake, S.S.

Long-Term Changes of Aquatic Invasive Plants and Implications for Future Distribution: A Case Study Using a Tank Cascade System in Sri Lanka. Climate 2021, 9, 31.

https://doi.org/10.3390/cli9020031

Academic Editor: Marcello Vitale

Received: 9 January 2021

Accepted: 5 February 2021

Published: 9 February 2021

Publisher's Note: MDPI stays neutral with regard to jurisdictional claims in published maps and institutional affiliations.

Copyright: (c) 2021 by the authors. Licensee MDPI, Basel, Switzerland. This article is an open access article distributed under the terms and conditions of the Creative Commons Attribution (CC BY) license (https:/ / creativecommons.org/licenses/by/ $4.0 /)$.

\begin{abstract}
Climate variability can influence the dynamics of aquatic invasive alien plants (AIAPs) that exert tremendous pressure on aquatic systems, leading to loss of biodiversity, agricultural wealth, and ecosystem services. However, the magnitude of these impacts remains poorly known. The current study aims to analyse the long-term changes in the spatio-temporal distribution of AIAPs under the influence of climate variability in a heavily infested tank cascade system (TCS) in Sri Lanka. The changes in coverage of various features in the TCS were analysed using the supervised maximum likelihood classification of ten Landsat images over a 27-year period, from 1992 to 2019 using ENVI remote sensing software. The non-parametric Mann-Kendall trend test and Sen's slope estimate were used to analyse the trend of annual rainfall and temperature. We observed a positive trend of temperature that was statistically significant $(p$ value $<0.05)$ and a positive trend of rainfall that was not statistically significant ( $p$ values $>0.05$ ) over the time period. Our results showed fluctuations in the distribution of AIAPs in the short term; however, the coverage of AIAPs showed an increasing trend in the study area over the longer term. Thus, this study suggests that the AIAPs are likely to increase under climate variability in the study area.
\end{abstract}

Keywords: climate change; climate variability; land use change; Mann-Kendall statistical test; Sen's slope estimator; supervised maximum likelihood classification

\section{Introduction}

Freshwater ecosystems are characterised by high levels of biodiversity, and they also provide vital ecosystem services to sustain life on earth [1]. These important ecosystems account for merely $0.8 \%$ of the land surface on earth, but a vast number of species $(100,000$ species or $6 \%$ of total species) that live on the planet depend on this vital ecosystem [2]. Moreover, these aquatic systems contain the highest number of species threatened with extinction along with more imperiled habitats; thus, they are considered as severely endangered ecosystems on earth $[3,4]$. Negative influences on this ecosystem have been attributed to a variety of causes i.e., land use changes, nutrient and chemical pollution, climate change, and invasive plants [5]. The ecological impacts caused by aquatic invasive alien plants (AIAPs) on freshwater habitats is widely acknowledged. It is one of the key drivers of biodiversity depletion in fresh water systems. Aquatic invasive alien plants cause a significant impact on the richness of native plants and animals across many aquatic habitats [6-8]. They change structure and function of aquatic systems and rapidly change habitats [1]. Ecosystem services are disrupted resulting in direct economic losses [9]. Certain AIAPs (i.e., Salvinia molesta and Eichhornia crassipes) proliferate rapidly and produce a mat on the water surface, which eventually impedes light and oxygen supply to the lower level plants and animals, leading to destruction of the entire ecosystem $[10,11]$. In 
addition, increased rates of sedimentation and evapotranspiration of these plants result in negative impacts on water quality [12]. Freshwater ecosystems are highly susceptible to the invasion of AIAPs, which are generally pervasive due to high propagule pressure [2,6]. As climate-based species distribution models predict, the threats from invasive species to freshwater aquatic ecosystems is likely to be aggravated in the future [1]. Generally, weak barriers in such systems facilitate the rapid movement of IAPS [13]. Moreover, various anthropogenic activities support the spread of AIAPs through relaxing natural barriers for the vectors to spread [14]. Agriculture is highly affected by AIAPs, as they make negative impacts on agricultural operations. Further, they interfere with the irrigation water supply as they reduce the water-holding capacity of water bodies [15]. In addition, they are a key challenge to the irrigation, fisheries, water use, human health, livelihoods, and the environment $[16,17]$.

Scientific literature has confirmed that the global climate is changing, due to anthropogenic activities (i.e., fossil fuel use, land use change, and agriculture) and natural climatic variability [18]. The results of climate change, such as changes in water temperatures, salinisation, sea level rise, and streamflow patterns, can influence the spread of AIAPs in freshwater systems [19]. This highlights that climate change has a close relationship with the temporal and spatial distribution of AIAPs, which significantly make alterations in biodiversity patterns in aquatic systems $[8,20,21]$. The understanding on range dynamics (i.e., geographic range shifts) of AIAPs in response to climate change is rather limited compared with terrestrial or marine species [19]. This can be perhaps due to aquatic ecosystems having received rather less research attention compared with the other ecosystems [1]. Climate change, along with other global change stressors, can have profound impacts on invasive species composition and spread dynamics [22,23]. Thus, the influence of climate change on AIAPs distribution is undeniable; however, it is perhaps overlooked by the scientific community due to the complex nature of their interactions with the environment $[1,24,25]$.

Understanding the invasion risk in aquatic systems is imperative for developing effective planning and management efforts [26,27]. At present, there is anecdotal evidence on the spatial and temporal distribution of AIAPs in the freshwater systems, particularly in developing tropical countries, as they have received the least research attention [28]. For instance, the use of species distribution models to predict the potential distribution of AIAPs in developing countries is affected by data limitations [29,30]. Examining land use and land cover changes using satellite images is a reliable tool for monitoring the changes in ecosystems on earth [31]. However, its potential is yet to be exploited to protect global biodiversity, as anticipated by the Convention on Biological Diversity (i.e., Aichi biodiversity targets) [32]. Freely available Landsat satellite imageries collected since the early 1980s can be used to map land use areas and monitor changes over a certain period of time $[33,34]$. The pivotal role of Landsat images has been useful in many ecological applications of remote sensing, i.e., ecological monitoring, land use land cover changes, and biodiversity conservation [35]. Spatial distribution changes of land use can be obtained through analysing classified images at different time periods. Such an analysis in aquatic systems provides important information to obtain an understanding of the long-term range dynamics and potential risks of aquatic invaders.

Biological invasions potentially exert increased risks on aquatic systems rather than terrestrial systems [36,37]. In Sri Lanka too, the issues posed by AIAPs are seemingly more serious than the terrestrial plant invaders in terms of the magnitude of the problem. Thousands of major and minor tanks (man-made reservoirs) located particularly in the dry zone of the country are infested with world's worst AIAPs, such as S. molesta and E. crassipes. The dry zone tank cascade system (TCS), a sensitive yet self-sustaining freshwater ecosystem habitat, provides irrigation water for agriculture (i.e., paddy) in the area [38]. At present, this system is infested with aquatic weeds, which is mostly dominated by AIAPs (i.e., S. molesta and E. crassipes) and representation of other native weeds is comparatively less. Thus, to better understand how AIAPs are influenced by climate change in this TCS, we conducted a research study that examined the long-term trend analysis of climate data 
and its relation to the distribution of AIAPs. The specific aims of this study were to (i) evaluate the long-term spatial and temporal spread dynamics of AIAPs, (ii) analyse the longterm trends of rainfall and temperature, (iii) examine how IAPS distribution may change in response to climate change and investigate potential impacts on agriculture. To the best of our knowledge, no systematic study has been undertaken to understand the influence of climate variations on the range dynamics of AIAPs in Sri Lanka. Identifying changes in surface cover of AIAPs is vital to fully understand how they respond to climate change and further to provide implications and impetus towards evidence-based decision making.

\section{Materials and Methods}

\subsection{Study Area}

The present study was conducted in the Nachchaduwa tank and three cascade systems, located in the Anuradhapura district encompassing five divisional secretariats of Thirappane, Nachchaduwa, Nuwaraam Palatha East, Ipalogama, and Kekirawa on latitude $8^{\circ} 6^{\prime}-8^{\circ} 18^{\prime} \mathrm{N}$ and $80^{\circ} 27^{\prime}-80^{\circ} 36^{\prime} \mathrm{E}$, Sri Lanka (Figure 1). A tank cascade system consists of small man-made reservoirs that are connected by canals and spillways and drain into a large water reservoir $[39,40]$. The Nachchaduwa tank cascade system (here after TCS) comprises of 67 tanks of different sizes with a total area of approximately $26 \mathrm{~km}^{2}$ (blue colour area in Figure 1) that spreads over an area located along a generally flat, undulating to rolling terrain. This area receives runoff water mainly from the northeast monsoon rains in the months of September to February. This unique agricultural system provides an outstanding service by conserving biodiversity and ecosystem services in the landscape.

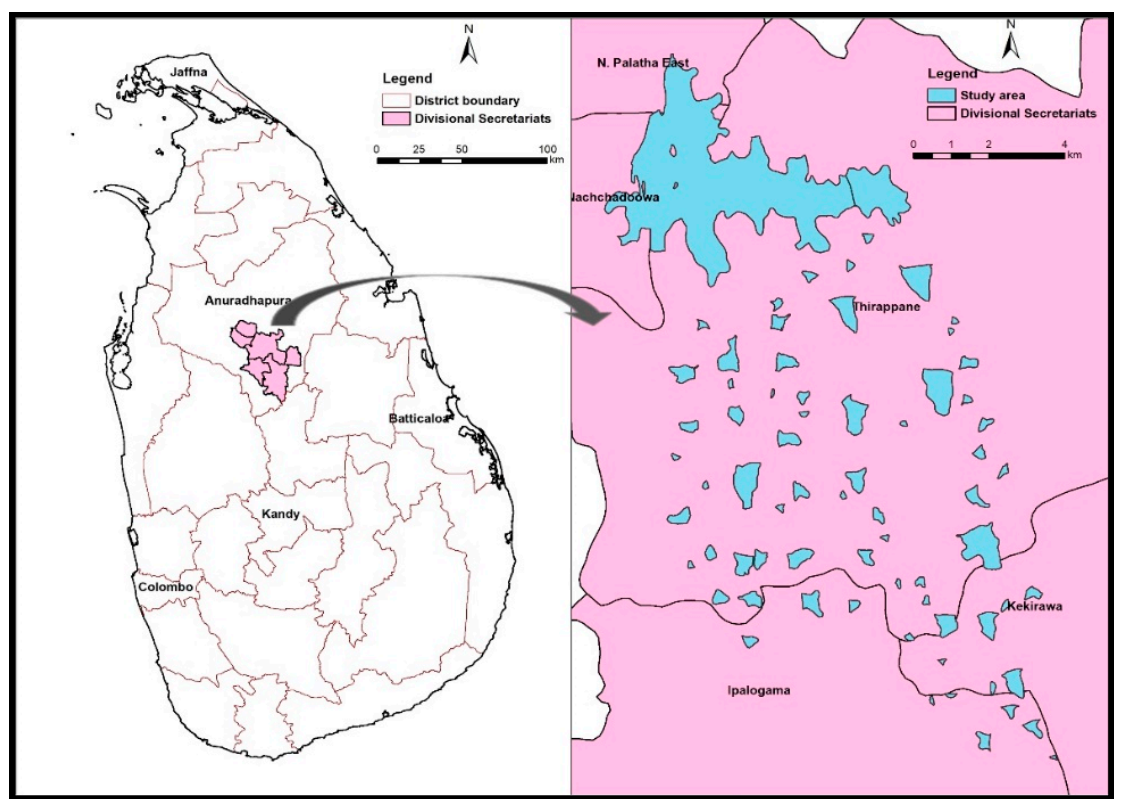

Figure 1. Location of the tank cascade system (study area) showing relevant administrative divisions.

The TCS, which has been sustained for centuries, is presently confronted with challenges from aquatic plant invasion, which is particularly linked to impacts of climate change. At present, a majority of the cascade tanks are covered with some of the world's worst invasive plants: S. molesta and E. crassipes. Salvinia molesta and E. crassipes were introduced to Sri Lanka as early as 1930 and 1905 respectively and soon dispersed to the water bodies across the country [11,41]. By the early 1980s, S. molesta and E. crassipes had infested the tanks system in the dry zone, where the majority of the tanks were entirely covered with a thick growth $[11,42]$. 


\subsection{Analysis of Satellite Images to Assess AIAPs Distribution}

\subsubsection{Landsat Data}

Landsat 4-5, 7, and 8 remote sensing data were employed in this study. Multi-spectral Landsat images were downloaded in GeoTIFF format for the years 1992, 1996, 2000, 2003, 2007, 2010, 2013, 2016, 2017, and 2019 from USGS Earth explorer Website (https: / / earthexplorer.usgs.gov/). Thus, the gap between data acquisitions was approximately similar to make a comparative analysis of the changes. The images were of good quality with relatively few clouds over the area of interest. Clouds and cloud shadows influence image classifications, and it was challenging to find cloud-free Landsat images, which is a frequent problem in tropical countries $[33,43,44]$. Thus, accessibility to good quality Landsat images was an issue in this study region, which restricted the number of images that can be used in the analysis. The selected Landsat images were only good quality images during the first quarter (JFM) that were not affected (or minimally affected) by clouds and cloud shadows during the study period 1992-2019. The details of the imageries used in this study are presented in Table 1. The northeast monsoon brings rain to the dry zone from September to February, and water bodies in this area become full by the first few months of the year. Thus, images acquired during the first quarter of the year (wet season) were selected to avoid possible influences attributed to seasonal changes (i.e., water level fluctuations) of AIAPs distribution over the period of time and to examine long-term changes.

Table 1. Description of satellite imageries used in the study.

\begin{tabular}{ccccc}
\hline $\begin{array}{c}\text { Date of } \\
\text { Acquisition }\end{array}$ & Mission & $\begin{array}{c}\text { WRS } \\
\text { Path/Row }\end{array}$ & $\begin{array}{c}\text { Landsat Sensor } \\
\text { Bpatial } \\
\text { Resolution } \\
\text { (meters) }\end{array}$ \\
\hline $25-01-1992$ & Landsat 4-5 & $141 / 54$ & TM & Bands 1 7 \\
D8-03-1996 & Landsat 4-5 & $141 / 54$ & TM & Bands 1 7 \\
$23-01-2000$ & Landsat 7 & $141 / 54$ & ETM+ & Bands 1 8 \\
$31-01-2003$ & Landsat 7 & $141 / 54$ & ETM+ & Bands 1 8 \\
$07-03-2007$ & Landsat 4-5 & $141 / 54$ & TM & Bands 1 7 \\
$27-02-2010$ & Landsat 4-5 & $141 / 54$ & TM & Bands 1 7 \\
$21-03-2013$ & Landsat 8 & $142 / 54$ & OLI, TIRS & Bands 1 9/10 11 \\
$27-01-2016$ & Landsat 8 & $141 / 54$ & OLI, TIRS & Bands 1 9/10 11 \\
$13-01-2017$ & Landsat 8 & $141 / 54$ & OLI, TIRS & Bands 1 9/10 11 \\
$03-01-2019$ & Landsat 8 & $141 / 54$ & OLI, TIRS & Bands 1 9/10 11 \\
\hline
\end{tabular}

We received the updated geospatial boundary demarcation vector data (shapefile) of TCS from the Department of Agriculture Sri Lanka, which was used to mask the study area.

\subsubsection{Image Processing}

Image processing, which involves the conversion of digital number values of pixels to useful information, is undertaken in three consecutive steps: pre-processing, image enhancement, and classification [45]. We used ENVI version 5.5 (Exelis Visual Information Solutions, Boulder, CO, USA) for satellite image processing and further analyses. ArcMap version 10.4.1 was employed for producing maps. Image pre-processing is vital to improving image quality and performance, which is done by suppressing unnecessary distortions while enhancing some image features [46]. Digital image processing techniques, radiometric calibration, and dark object subtraction were used to enhance Landsat images before classification. Radiometric correction was undertaken as the study compared multiple images across a long period of time [47]. This technique corrects for errors in digital number values of image pixels and improves the interpretability and quality of remotely sensed data [33,48]. Furthermore, we used dark-object subtraction to remove atmospheric scattering effects before analysis for efficient extraction of land cover information [49]. It is a simple but widely used and accepted atmospheric correction approach [34]. 
Image classification assigns pixels of the image into groups of similar land use classes/clusters on the earth's surface [45,50]. Landsat satellite remote sensing data contain different spectral variations for different feature types [51]. Thus, features in the study area were classified using the supervised classification technique. This technique assigns specific pixel value ranges for land use classes [45]. Therefore, for each of the pre-processed images, local knowledge of the study area and visual interpretation by referring to historical Google Earth images were used to identify the major land cover types that were common in all the time series images. Through this process, the four features identified and delineated as classification classes were water, AIAPs, non-aquatic plants, and open areas (Table 2). Aquatic plants found on the water surface of the TCS generally represent E. crassipes and S. molesta; however, other native and non-native aquatic plants could be find occasionally.

Table 2. Description of the four land use classes used in the image classification.

\begin{tabular}{|c|c|}
\hline Land Use Type & Description \\
\hline Non-aquatic plants & $\begin{array}{l}\text { Areas covered by non-aquatic plants (i.e., dense forests, sparse } \\
\text { forests, agricultural plants, plantations) inside tank cascade system }\end{array}$ \\
\hline AIAPs & Aquatic plants covering the water surface in the tank system \\
\hline Open areas & $\begin{array}{l}\text { Sedimented areas/barren lands, paddy cultivations and built up } \\
\text { areas (i.e., footpaths) }\end{array}$ \\
\hline Water & $\begin{array}{c}\text { Deep and shallow water in tanks and streams, which includes both } \\
\text { pure and sedimented water }\end{array}$ \\
\hline
\end{tabular}

For each of the training class, regions of interest (ROIs) were defined using a specified colour code. Visualisation of the various features during the creation of ROIs was enhanced through false colour composite by variation of the Red-Green-Blue (RGB) bands. ROIs were randomly selected as much as possible for better capturing pixel variability. For image classification, maximum likelihood supervised classification was used. This method assigns pixels to the nearest classification class (highest probability of belonging to a class) while running the classification.

\subsubsection{Accuracy Assessment}

In maximum likelihood classification, some pixels can be classified incorrectly due to an inconsistent distribution of data [52]. In order to provide reliable results, image classification studies should produce a high degree of overall accuracy, which provides a quantitative measure of how effectively pixels are categorised into respective feature classes [53]. Thus, accuracy assessment of the classified images plays an important role in order to assess the reliability of remote sensing-derived information contained in the maps and to provide reliable input data for subsequent scientific investigations and policy decisions [43,54]. In the study, ground truth ROIs were randomly acquired for accuracy assessment by making reference to historical Google Earth imagery of the same year, as field-based data collection is not possible for accuracy assessment of historical images. The number of ground reference pixels that were developed by drawing polygons around the features of interest varied temporarily for different land cover classes, and this was based on ease of identification and variabilities within the classes. Therefore, the assessment was carried out using $117,163,144,173,206,155,229,280,125$, and 187 pixels for the 1992, 1996, 2000, 2003, 2007, 2010, 2013, 2016, 2017, and 2019 images, respectively. Statistical analysis of the classified images and the ground reference pixels for the various years was done using confusion matrix (error matrix) in ENVI. Accuracy of the classification was assessed in terms of overall accuracy, kappa coefficient, producer's accuracy, and user's accuracy. The kappa statistic, that ranges from 0 (no agreement) to 1 (complete agreement), is highly recommended for assessing classification accuracy as it provides interclass discrimination specifically than overall accuracy [55]. Using ArcMap software, the areas covered by each land cover type were extracted from the classified images. 


\subsection{Long-Term Trend Analysis of Climate Variables}

To understand and describe the variations in climate parameters in the study area, we analysed temporal climate data of the Anuradhapura district over the period 1990-2019, obtained from the Department of Meteorology, Sri Lanka. These climate data are from one weather station (Anuradhapura) that covers the TCS and surrounding areas. We analysed time-series data of climate parameters, annual average mean temperature, and total annual rainfall ranging from 1990 to 2019 to understand the variability and trends that could influence AIAPs distribution in the long term. We tested the statistical significance of the trend (i.e., $\alpha=0.10,0.05)$ using the widely used non-parametric Mann-Kendall trend analysis statistical test $[56,57]$ and Sen's slope estimator [58] using XLSTAT software (Addinsoft 2020; https:/ / www.xlstat.com). The Mann-Kendall test determines whether there is a significant positive or negative trend of the variables over time. The Sen's slope estimator assesses the magnitude and direction of the detected trend in the sample of $\mathrm{N}$ pairs of data, which results in a positive value $(>0)$ indicating an increasing trend and a negative value $(<0)$ indicating a decreasing trend $[59,60]$. The relationship between the climate variability and AIAPs distribution in the study area over the period was examined.

\section{Results}

\subsection{Accuracy Assessment and Land Use}

The results of the accuracy assessment of the classified images for the ten-time periods are displayed in Table 3. We obtained good accuracy estimates for all ten images, with $>87 \%$ for overall accuracy and $>0.8$ for the Kappa coefficient for each of the images. According to Lea and Curtis [61], these accuracy levels are satisfactory for the calculation of land use/cover areas. Thus, our classification results are robust with good performance.

Table 3. Results of accuracy assessment (confusion matrix of land use/cover maps of 1992, 1996, 2000, 2003, 2007, 2010, 2013, 2016, 2017, and 2019.

\begin{tabular}{|c|c|c|c|c|c|c|c|}
\hline \multicolumn{8}{|c|}{ Ground Truth (Pixels) } \\
\hline Class & $\begin{array}{l}\text { Non-Aquatic } \\
\text { plants }\end{array}$ & AIAPs & Open Areas & Water & Total & $\begin{array}{l}\text { Producer's } \\
\text { Accuracy }\end{array}$ & $\begin{array}{l}\text { User's } \\
\text { Accuracy }\end{array}$ \\
\hline $\begin{array}{l}\text { Non-aquatic } \\
\text { plants }\end{array}$ & 26 & 0 & 0 & 0 & 26 & $95.8 \%$ & $100 \%$ \\
\hline AIAPs & 1 & 29 & 0 & 0 & 30 & $100.0 \%$ & $96 \%$ \\
\hline Open areas & 0 & 0 & 31 & 0 & 31 & $100.0 \%$ & $100 \%$ \\
\hline Water & 0 & 0 & 0 & 30 & 30 & $100.0 \%$ & $100 \%$ \\
\hline Total & 27 & 29 & 31 & 30 & 117 & - & - \\
\hline \multicolumn{8}{|c|}{ Overall Accuracy = 99.04\%; Kappa Coefficient = 0.9872} \\
\hline \multicolumn{8}{|c|}{ - $\quad$ Error matrix for 1996 Landsat 4-5 TM classified image. } \\
\hline \multicolumn{8}{|c|}{ Ground Truth (Pixels) } \\
\hline Class & $\begin{array}{c}\text { Non-Aquatic } \\
\text { Plants }\end{array}$ & AIAPs & Open Areas & Water & Total & $\begin{array}{c}\text { Producer's } \\
\text { Accuracy }\end{array}$ & $\begin{array}{c}\text { User's } \\
\text { Accuracy }\end{array}$ \\
\hline $\begin{array}{l}\text { Non-aquatic } \\
\text { plants }\end{array}$ & 26 & 0 & 0 & 0 & 26 & $96.0 \%$ & $100 \%$ \\
\hline AIAPs & 0 & 27 & 0 & 4 & 31 & $79.4 \%$ & $87 \%$ \\
\hline Open areas & 1 & 0 & 28 & 0 & 29 & $77.8 \%$ & $96 \%$ \\
\hline Water & 0 & 7 & 8 & 62 & 77 & $93.9 \%$ & $81 \%$ \\
\hline Total & 27 & 34 & 36 & 66 & 163 & - & - \\
\hline \multicolumn{8}{|c|}{ Overall Accuracy = 87.68\%; Kappa Coefficient $=0.8248$} \\
\hline (a) Error m & $\mathrm{x}$ for 2000 Lan & ETM+ & ified image & & & & \\
\hline
\end{tabular}


Table 3. Cont.

\begin{tabular}{|c|c|c|c|c|c|c|c|}
\hline \multicolumn{8}{|c|}{ Ground Truth (Pixels) } \\
\hline Class & $\begin{array}{l}\text { Non-Aquatic } \\
\text { Plants }\end{array}$ & AIAPs & Open Areas & Water & Total & $\begin{array}{l}\text { Producer's } \\
\text { Accuracy }\end{array}$ & $\begin{array}{l}\text { User's } \\
\text { Accuracy }\end{array}$ \\
\hline Non-aquatic plants & 34 & 0 & 2 & 0 & 36 & $87.50 \%$ & $94.79 \%$ \\
\hline AIAP & 0 & 27 & 2 & 4 & 33 & $100.00 \%$ & $81.82 \%$ \\
\hline Open areas & 5 & 0 & 27 & 0 & 32 & $77.14 \%$ & $84.38 \%$ \\
\hline Water & 0 & 0 & 4 & 39 & 43 & $90.70 \%$ & $90.70 \%$ \\
\hline Total & 39 & 27 & 35 & 43 & 144 & - & - \\
\hline \multicolumn{8}{|c|}{ Overall Accuracy $=88.28 \%$; Kappa Coefficient $=0.8429$} \\
\hline
\end{tabular}

(b) Error matrix for 2003 Landsat 7 ETM+ classified image

\begin{tabular}{|c|c|c|c|c|c|c|c|}
\hline \multicolumn{8}{|c|}{ Ground Truth (Pixels) } \\
\hline Class & $\begin{array}{l}\text { Non-Aquatic } \\
\text { Plants }\end{array}$ & AIAPs & Open Areas & Water & Total & $\begin{array}{l}\text { Producer's } \\
\text { Accuracy }\end{array}$ & $\begin{array}{c}\text { User's } \\
\text { Accuracy }\end{array}$ \\
\hline Non-aquatic plants & 34 & 0 & 5 & 0 & 39 & $94.1 \%$ & $87 \%$ \\
\hline AIAPs & 0 & 36 & 0 & 0 & 36 & $100.0 \%$ & $100 \%$ \\
\hline Open areas & 0 & 0 & 33 & 4 & 37 & $86.8 \%$ & $89 \%$ \\
\hline Water & 2 & 0 & 0 & 59 & 61 & $93.7 \%$ & $97 \%$ \\
\hline Total & 36 & 36 & 38 & 63 & 173 & - & - \\
\hline
\end{tabular}

Overall Accuracy $=93.57 \%$; Kappa Coefficient $=0.9125$

(c) Error matrix for 2007 Landsat 4-5 TM classified image

\begin{tabular}{cccccccc}
\hline & \multicolumn{3}{c}{ Ground Truth (Pixels) } \\
\hline Class & $\begin{array}{c}\text { Non-Aquatic } \\
\text { Plants }\end{array}$ & AIAPs & Open Areas & Water & Total & $\begin{array}{c}\text { Producer's } \\
\text { Accuracy }\end{array}$ & $\begin{array}{c}\text { User's } \\
\text { Accuracy }\end{array}$ \\
\hline Non-aquatic plants & 59 & 0 & 1 & 0 & 60 & $92.0 \%$ & $98 \%$ \\
AIAPs & 0 & 48 & 0 & 0 & 48 & $85.7 \%$ & $100 \%$ \\
Open areas & 4 & 0 & 32 & 0 & 36 & $97.0 \%$ & $89 \%$ \\
Water & 1 & 8 & 0 & 53 & 62 & $100.0 \%$ & - \\
Total & 64 & 56 & 33 & 53 & 206 & - & -
\end{tabular}

(d)-(f) Error matrix for 2010 Landsat 4-5 TM classified image

\begin{tabular}{cccccccc}
\hline & \multicolumn{3}{c}{ Ground Truth (Pixels) } \\
\hline Class & $\begin{array}{c}\text { Non-Aquatic } \\
\text { Plants }\end{array}$ & AIAPs & Open Areas & Water & Total & $\begin{array}{c}\text { Producer's } \\
\text { Accuracy }\end{array}$ & $\begin{array}{c}\text { User's } \\
\text { Accuracy }\end{array}$ \\
\hline Non-aquatic plants & 30 & 4 & 2 & 0 & 36 & $100.0 \%$ & $83 \%$ \\
AIAPs & 0 & 41 & 0 & 0 & 41 & $80.4 \%$ & $100 \%$ \\
Open areas & 0 & 2 & 39 & 0 & 41 & $95.1 \%$ & $95 \%$ \\
Water & 0 & 4 & 0 & 33 & 37 & $100.0 \%$ & - \\
Total & 30 & 51 & 41 & 33 & 155 & - & - \\
Overall Accuracy & $=92.26 \% ;$ Kappa Coefficient $=0.8964$ & & & &
\end{tabular}

(g) Error matrix for 2013 Landsat 8 OLI, TIRS classified image

\begin{tabular}{cccccccc}
\hline & \multicolumn{3}{c}{ Ground Truth (Pixels) } \\
\hline Class & $\begin{array}{c}\text { Non-Aquatic } \\
\text { Plants }\end{array}$ & AIAPs & Open areas & Water & Total & $\begin{array}{c}\text { Producer's } \\
\text { Accuracy }\end{array}$ & $\begin{array}{c}\text { User's } \\
\text { Accuracy }\end{array}$ \\
\hline Non-aquatic plants & 29 & 0 & 0 & 0 & 29 & $86.7 \%$ & $100 \%$ \\
AIAPs & 1 & 62 & 0 & 0 & 63 & $92.4 \%$ & $98 \%$ \\
Open areas & 3 & 5 & 44 & 0 & 52 & $100 \%$ & $100 \%$ \\
Water & 0 & 0 & 0 & 85 & 85 & $-100 \%$ \\
Total & 33 & 67 & 44 & 85 & 229 & -
\end{tabular}

Overall Accuracy $=95.86 \%$; Kappa Coefficient $=0.9425$

(h) Error matrix for 2016 Landsat 8 OLI, TIRS classified image 
Table 3. Cont.

\begin{tabular}{|c|c|c|c|c|c|c|c|}
\hline \multicolumn{8}{|c|}{ Ground Truth (Pixels) } \\
\hline Class & $\begin{array}{l}\text { Non-Aquatic } \\
\text { Plants }\end{array}$ & AIAPs & Open Areas & Water & Total & $\begin{array}{c}\text { Producer's } \\
\text { Accuracy }\end{array}$ & $\begin{array}{c}\text { User's } \\
\text { Accuracy }\end{array}$ \\
\hline Non-aquatic plants & 81 & 4 & 1 & 0 & 86 & $95.5 \%$ & $94 \%$ \\
\hline AIAPs & 3 & 50 & 7 & 0 & 60 & $83.3 \%$ & $84 \%$ \\
\hline Open areas & 0 & 0 & 64 & 0 & 64 & $82.1 \%$ & $100 \%$ \\
\hline Water & 1 & 6 & 6 & 57 & 70 & $100.0 \%$ & $81 \%$ \\
\hline Total & 85 & 60 & 78 & 57 & 280 & - & - \\
\hline Overall Accuracy = & $.05 \%$; Карра С & icient $=$ & & & & & \\
\hline
\end{tabular}

(i) Error matrix for 2017 Landsat 8 OLI, TIRS classified image

\begin{tabular}{cccccccc}
\hline & \multicolumn{3}{c}{ Ground Truth (Pixels) } \\
\hline Class & $\begin{array}{c}\text { Non-Aquatic } \\
\text { Plants }\end{array}$ & AIAPs & Open Areas & Water & Total & $\begin{array}{c}\text { Producer's } \\
\text { Accuracy }\end{array}$ & $\begin{array}{c}\text { User's } \\
\text { Accuracy }\end{array}$ \\
\hline Non-aquatic plants & 27 & 0 & 0 & 0 & 27 & $95.0 \%$ & $100 \%$ \\
AIAPs & 0 & 32 & 0 & 0 & 32 & $86.5 \%$ & $100 \%$ \\
Open areas & 1 & 0 & 21 & 0 & 22 & $100.0 \%$ & $94 \%$ \\
Water & 0 & 5 & 0 & 39 & 44 & $100.0 \%$ & $89 \%$ \\
Total & 28 & 37 & 21 & 39 & 125 & - & -
\end{tabular}

Overall Accuracy = 94.88\%; Kappa Coefficient $=0.9305$

(j) Error matrix for 2019 Landsat 8 OLI, TIRS classified image

\begin{tabular}{|c|c|c|c|c|c|c|c|}
\hline \multicolumn{8}{|c|}{ Ground Truth (Pixels) } \\
\hline Class & $\begin{array}{l}\text { Non-Aquatic } \\
\text { Plants }\end{array}$ & AIAPs & Open Areas & Water & Total & $\begin{array}{c}\text { Producer's } \\
\text { Accuracy }\end{array}$ & $\begin{array}{c}\text { User's } \\
\text { Accuracy }\end{array}$ \\
\hline Non-aquatic plants & 68 & 0 & 0 & 0 & 68 & $94.5 \%$ & $100 \%$ \\
\hline AIAPs & 1 & 32 & 7 & 0 & 40 & $100.0 \%$ & $79 \%$ \\
\hline Open areas & 3 & 0 & 24 & 0 & 27 & $77.4 \%$ & $90 \%$ \\
\hline Water & 0 & 0 & 0 & 52 & 52 & $100.0 \%$ & $100 \%$ \\
\hline Total & 72 & 32 & 31 & 52 & 187 & - & - \\
\hline \multicolumn{8}{|c|}{ Overall Accuracy $=94.16 \%$; Kappa Coefficient $=0.9191$} \\
\hline
\end{tabular}

The distribution of land uses in the study area over the period 1992-2019 is presented in Figure 2, whereas the temporal changes in coverage of various land uses during the study period are presented in Table 4. According to the figures, the coverages of AIAPs vary during the study period. The range dynamics of AIAPs is illustrated graphically in Figure 3, which shows a positive trend during the study period. The trends were statistically significant with $p$ values of 0.01 at $95 \%$ confidence level. Additional details relevant to area changes are provided in Table 5. Accordingly, we observed an overall increase of $28.6 \%$ of the coverage of AIAPs over the period from 1992 to 2019.

Table 4. Representation of areas of four land use classes of the classified images from 1992 to 2019.

\begin{tabular}{|c|c|c|c|c|c|c|c|c|c|c|}
\hline \multirow{2}{*}{ Land Use Class } & \multicolumn{10}{|c|}{ Area $\mathrm{km}^{2}$} \\
\hline & 1992 & 1996 & 2000 & 2003 & 2007 & 2010 & 2013 & 2016 & 2017 & 2019 \\
\hline $\begin{array}{c}\text { Non-aquatic } \\
\text { plants }\end{array}$ & 1.060 & 2.388 & 1.277 & 2.522 & 2.995 & 1.379 & 3.387 & 3.279 & 2.477 & 5.575 \\
\hline AIAPs & 2.762 & 2.023 & 2.339 & 2.561 & 2.887 & 3.429 & 3.687 & 3.258 & 3.670 & 3.551 \\
\hline Open areas & 5.340 & 6.303 & 4.812 & 8.100 & 7.351 & 10.323 & 4.190 & 4.967 & 8.571 & 4.751 \\
\hline Water & 17.190 & 15.639 & 17.925 & 13.170 & 13.119 & 11.223 & 15.089 & 14.850 & 11.635 & 12.476 \\
\hline Total & 26.353 & 26.353 & 26.353 & 26.353 & 26.352 & 26.353 & 26.353 & 26.354 & 26.353 & 26.353 \\
\hline
\end{tabular}




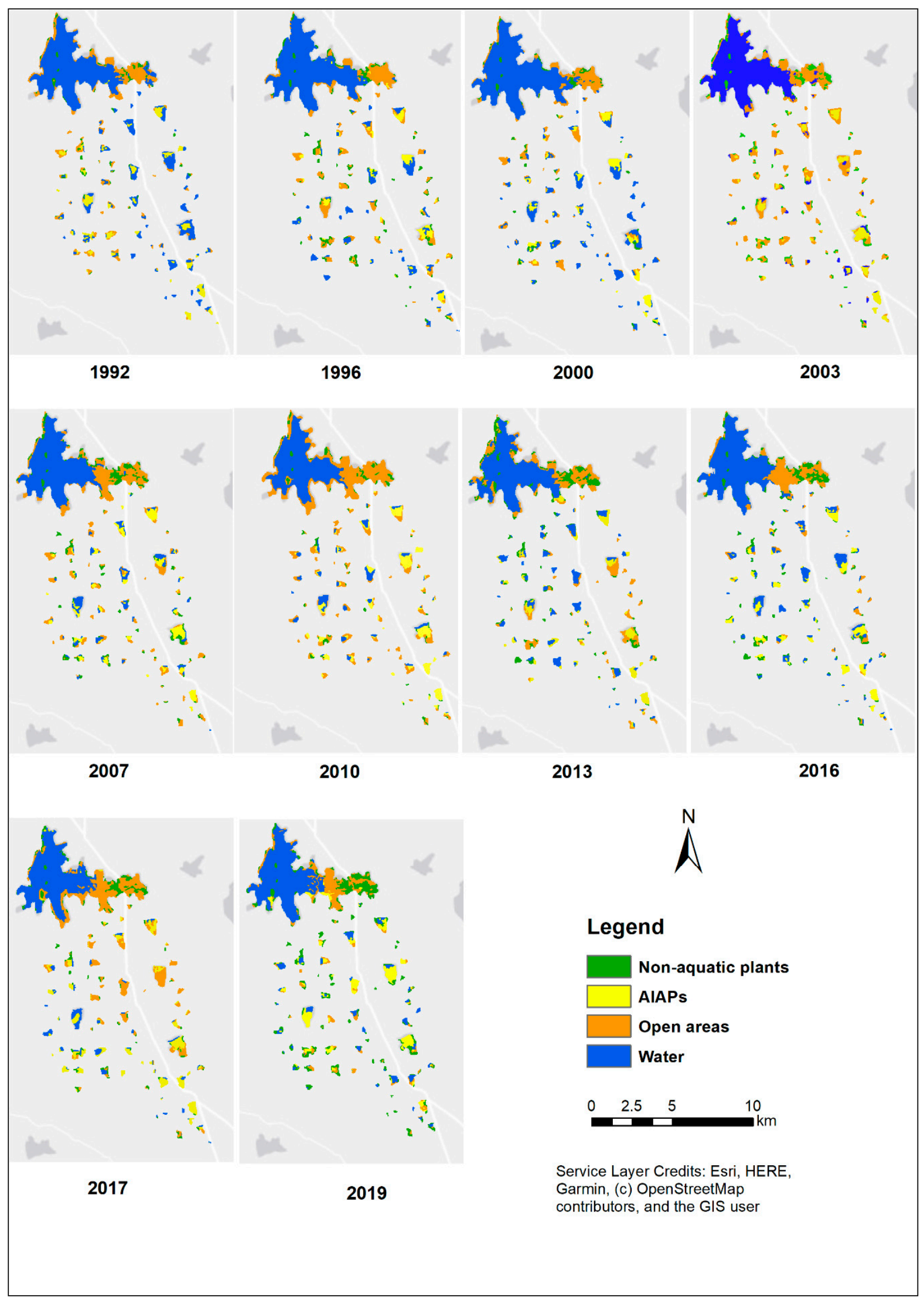

Figure 2. Spatial distribution of land covers in the study area from 1992 to 2019. 


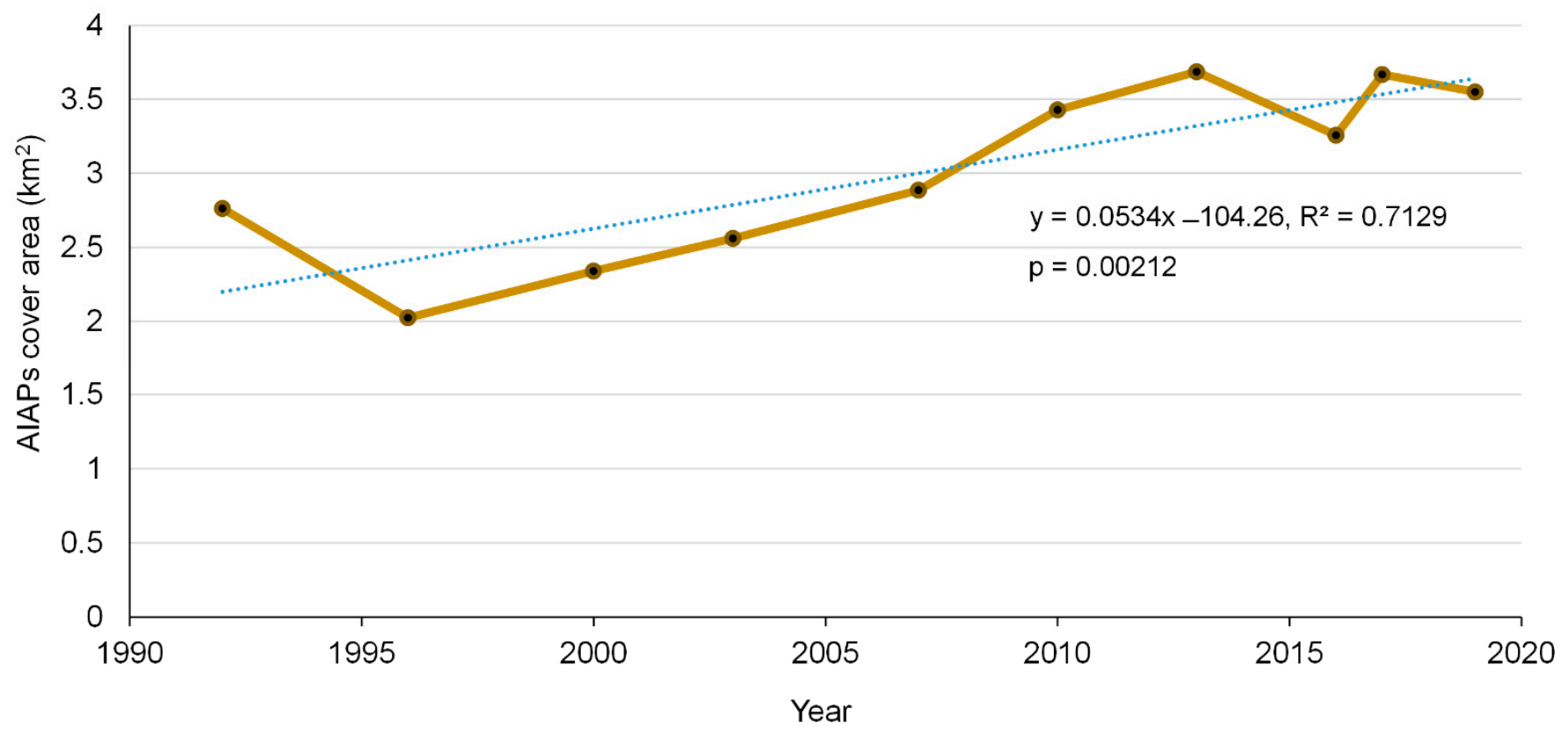

Figure 3. Historical trends of the area of cover of aquatic invasive alien plants in the study area of the period 1992-2019.

Table 5. Area changes of aquatic invasive alien plants in the study area from 1992 to 2019.

\begin{tabular}{ccc}
\hline Period & Change in AIAPs Area $\mathbf{( k m}^{\mathbf{2}} \mathbf{)}$ & $\begin{array}{c}\text { Rate of Change } \\
\mathbf{( \%} \text { change per year) }\end{array}$ \\
\hline $1992-1996$ & -0.74 & -0.18 \\
$1996-2000$ & 0.32 & 0.08 \\
$2000-2003$ & 0.22 & 0.07 \\
$2003-2007$ & 0.33 & 0.08 \\
$2007-2010$ & 0.54 & 0.18 \\
$2010-2013$ & 0.26 & 0.09 \\
$2013-2016$ & -0.43 & -0.14 \\
$2016-2017$ & 0.41 & 0.41 \\
$2017-2019$ & -0.12 & -0.06 \\
$1992-2019$ (overall) & 0.79 & 0.03 \\
\hline
\end{tabular}

\subsection{Long-Term Trend Analysis of Climate Variables}

The results of climate data analysis showing the magnitude of temporal variability of rainfall and temperature are presented in Figure 4. The annual average temperature and total annual rainfall show upward or increasing trends during the study period (Figure 4a). Figure $4 \mathrm{~b}$ shows that the highest amount of average monthly rainfall is recorded in the months of October to December, and the lowest is in the months of June to September. The average monthly temperature ranges from 26.1 to $29.6^{\circ} \mathrm{C}$. During the first quarter of the study years, the total rainfall showed an increasing trend, whereas average temperature shows a decreasing trend (Figure $4 \mathrm{c}$ ).

The summary results on long-term trend analysis based on Mann-Kendall and Sen's slope statistical tests for total annual rainfall and annual average temperature for the period of 1990-2019 in the TCS are presented in Table 6. At a significance level of 0.05, the $p$-value shows that the null hypothesis is rejected for annual average temperature, suggesting a significant trend in the time series; however, there is no trend for total rainfall at this significance level. We observed a significant trend for rainfall at a lower significance level of 0.1. According to Mahmood et al. [62], trends at $\alpha=0.05$ signify a strong signal of trend whereas trends at $\alpha=0.1$ signify a weak signal of trend. Thus, the analysis of climate data over the past three decades indicates a strong increasing signal for average temperature 
and weak increasing signal for total rainfall in the study area. We did not consider the seasonal changes of climate variables, as all images downloaded belonged to the same season of the year over the study period.

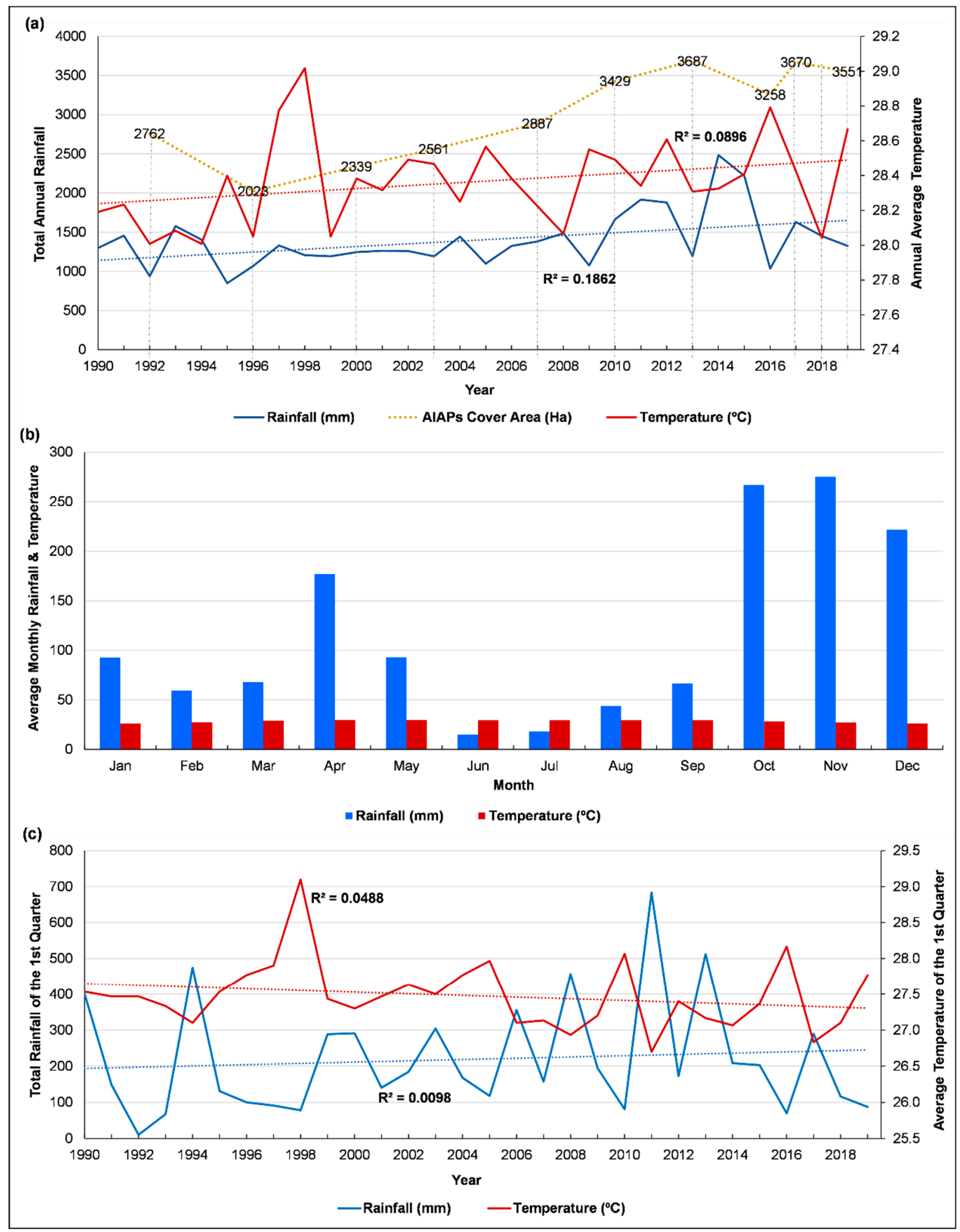

Figure 4. Temporal trends of temperature and rainfall in the study area from 1990 to 2019, where variability is between (a) annual average temperature and total annual rainfall (the dash-dotted vertical lines show the time periods used in land cover analysis), (b) average monthly rainfall and temperature, and (c) total rainfall and average temperature of the first quarter. 
Table 6. The summary test results of Mann-Kendall and Sen's slope test for annual average temperature and total annual rainfall time series.

\begin{tabular}{cccc}
\hline Series/Test & Kendall's Tau & $p$-Value & Sen's Slope \\
\hline Annual Average & 0.253 & 0.050 & 0.012 \\
Temperature & 0.246 & 0.056 & 14.725 \\
Total Annual Rainfall & 0 & & \\
\hline
\end{tabular}

\section{Discussion}

There have been very few published studies in the literature relevant to the range dynamics of AIAPs in freshwater aquatic systems. Although it is challenging, we explored the potential of medium-resolution satellite remote sensing data for assessing the longer-term changes of AIAPs spread in the freshwater aquatic system. In this study, we considered all species of AIAPs as one class, and individual species were not considered due to insufficient resolution of Landsat data. Thus, we did not undertake the accuracy assessment for individual species. As such, the high level of overall accuracy and Kappa coefficient we received for the images are explained. According to the findings, all fourland use classes (i.e., non-aquatic plants, AIAPs, open areas, water) display variations in area coverage. An analysis of the spread of AIAPs in the TCS show variable trend in coverage over the period 1992 to 2019. The changes fluctuate over short-term periods but increase over the 27-year period. We observed declines in the distribution of AIAPs in $1996(0.18 \%$ per year), in 2016 ( $0.14 \%$ per year), and in 2019 (0.06\% per year) relevant to the previous assessment year. However, the overall distribution of AIAPs from 1992 to 2019 showed a positive response with the increasing temporal variability of total annual rainfall and annual average temperature. The spread of AIAPS in the TCS has become a challenging issue for ecosystem functions in the study area and thus, the land managers should consider the negative consequences, particularly to agriculture. Distribution of land uses over the past two decades also signifies a general decline in water cover and increased distribution of non-aquatic plants in the study area. The siltation and sedimentation of tanks due to soil erosion because of intensive agriculture in the area is a major impediment for sustenance of the dry zone TCS [38]. Consequently, various native and non-native plants acquire these silted areas in the tank. Illegal cultivations on the tank bunds is another issue when water level fluctuates during the year. The distribution of open land area seems to be quite varying over the time period due to water level fluctuations.

Global warming is manifested by rising temperatures in air, water, and the earth's surface; and increased frequency of temperature extremes (i.e., hot days, heat waves) [63]. The rising temperature has implications on the distribution of non-native species under climate change $[64,65]$. The projected effects can make changes in aquatic systems by altering their pathways of introduction, establishment, spread, and distribution [19,64]. Under changing climate, ranges of non-native species are likely to expand into higher altitudes and latitudes. Experimental studies have confirmed that the $\mathrm{CO}_{2}$ enrichment and growth enhancement of AIAPs is strongly influenced by warmer temperatures $[66,67]$. Elevated temperature intensifies biomass production of aquatic macrophytes and influences the rapid development of shoots [68]. Thus, water temperature can be a crucial driver that influences the establishment, distribution, and impact of AIAPs [64]. The results of climate data analysis using regression analysis for the study period, Mann-Kendall test, and Sen's slope estimator showed strong significant positive trends for annual average temperature and a weaker significant positive trend for total annual rainfall in the study area at a significance level of 0.05 . The temperature increase in the study area can be due to various reasons, such as global warming, urbanisation, or atmospheric circulation, and such changes can lead to increased evapotranspiration and unusually dry spells [60].

The increasing spread of AIAPs that was observed in this study area can be attributed to several factors. Nitrogen deposition increases the abundance of exotics in an ecosystem while depleting its species richness [69]. Due to the increased usage of nitrogen fertiliser 
in agriculture, the excessive runoffs are added to the water bodies, resulting in increased growth of AIAPs [17]. Nitrogen-rich sediment deposits in the TCS might have resulted in the steady increase in non-aquatic plants cover in the study area. In TCS, the excess water of a tank upstream is diverted to the tank downstream through the paddy fields. Although this process enables an efficient use of water resources, it may ultimately cause increased nutrient content deposition in water bodies, resulting in a luxuriant growth of AIAPs [70]. The study revealed that small tanks are heavily infested by AIAPs, and the major tank is relatively free from invasions (Figure 2). This could be due to the continuous maintenance and cleaning of the major tank. The statistics given in Table 4 for AIAPs is mainly contributed by the infestations occurring in the small tanks. The distribution of AIAPs in the small tank system is significant relevant to the size of the tanks and thus, the effective management of AIAPs should be an important concern in the sustenance of the TCS. AIAPs coverage in the water tanks increased by around $28.6 \%$ over the 1992-2019 period.

In its 5th assessment report, the IPCC announced that the projected surface temperature change of the earth is expected to exceed $1.5^{\circ} \mathrm{C}$ by 2100 relative to $1850-1900$, and more intense and more frequent extreme precipitation events are predicted [71]. Climate plays a vital role in the geographic distribution of plant species [72]. Climate change makes alterations in the freshwater habitats, and such affected habitats have the potential to be highly vulnerable and adversely impacted by biological invaders $[7,73,74]$. We have observed positive relationships between climate variables and range dynamics of AIAPs in the study area during this period. Experimental studies have illustrated that the spatiotemporal distribution of plants is affected by variations in temperature and rainfall $[75,76]$. Through the bioclimatic modeling of three invasive plants, Egeria densa, Myriophyllum aquaticum, and Ludwigia spp., Gillard, et al. [77] highlighted that long-term changes occurring in the climate may have a substantial impact on the potential distribution of AIAPs in freshwater systems.

The results of this study imply a long-term decreasing trend of the area of surface water in the TCS. In addition, the findings suggest that the AIAPs have already expanded their coverage over the last few decades. We are not aware of the relative contribution of each variable to the AIAPs spread; however, in view of the relation of climate variability with the area of spread of AIAPs in the TCS, this expansion will continue in the future. Therefore, managing the potential negative consequences of AIAPs would be an increasing challenge to the land managers. The vegetative growth rate of AIAPs, such as Water hyacinth and Salvinia, is substantially high, and they constantly decay and produce a considerable amount of debris (biomass), which can cause the conversion of AIAPs areas to open areas over time [17]. The change in the land use pattern of the surrounding areas (for example, conversion from forest areas to agriculture) may also contribute to a high level of surface runoff, leading to increased soil erosion and silt deposition in the water bodies; the result of this is a reduction in the water-holding capacity of the tank system. AIAPs (such as water hyacinth) cause high levels of evapotranspiration, leading to significant water losses in water bodies [78]. In addition, they block irrigation canals and interfere with water supply to agriculture. Thus, the expansion of AIAPS would have severe negative consequences for agricultural production, as TCS serve as the main source of water for irrigated agriculture in this area.

Therefore, the continuous monitoring and evaluation of potential impacts of climate changes on freshwater aquatic systems is of great importance. Remote sensing image analysis, based on the supervised maximum likelihood classification method, provides important information for land managers, such as spatiotemporal spread patterns, range changes, and potential distributions of AIAPs. Such information is reliable and can be included in the formulation of policies and management actions for better land use management. In the TCS, propagules can disperse from one tank to the other easily, especially during rainy periods, as tanks are interconnected. Thus, this should be considered while formulating necessary management actions. The findings of the present study may be important for conservation planners and water resource managers to be vigilant on AIAPs issue as a potential impact of climate variability and climate change. The results of this 
study also provide implications for the use of Landsat data for similar ecological studies in the region.

\section{Limitations and Challenges of the Study}

The information provided by the moderate resolution Landsat data is not sufficient to fully differentiate AIAPs to the species level. Aquatic invaders may share the same habitat niche with other non-AIAPs; thus, perhaps our results may overestimate the spread of AIAPs. However, the primary occupants in the tank system are AIAPs (personal observations by 1st and 4th authors), and non-AIAPs have always been a minor component. Thus, we presume that the interference by non-AIAPs would be minimal for the analysis. Further, we have taken all possible steps to correct and enhance the quality and improve the appearance of Landsat images. Practically, classification is sometimes challenging for some pixels, as the classification algorithm may not identify land uses correctly due to certain reasons (i.e., when water bodies are turbid or depending on the level of chlorophyll-a contents in water), and such situations may interfere with the classifications [51]. Heavy rainfall can inundate shallow open areas, and thus, such areas can be classified as water. While classifying the images, there was a challenge with the weeds (non-aquatic or nonnative plants) growing on the silted areas because of the similar spectral reflectance with AIAPs. We minimised this error by using the Google Earth image of the same year, as the AIAPs could be identified through their distinct growing pattern and coloration, which was unique and different from other plants. Although Google Earth is a useful image analysis tool, such historical images are also not sharp enough, particularly those before 2011.

In this study, we did not intend to look at seasonal variations in the spread of the AIAPs; our key aim was to look at long-term changes. That is the reason why we chose all the images of the same season. Hence, even if there were seasonal variations, by keeping all the images to one season, we would still be able to pick the long-term trends. Seasonal changes and effects are removed by selecting images of the same time period. This is an appropriate and accepted methodology for looking at long-term changes. Our results of post-classification represent only one land use in one pixel, and it may overlook small sub-pixel level conversions [79]. However, in reality, some pixels represent several land uses. The pixel size we used in these Landsat images $(30 \mathrm{~m} \times 30 \mathrm{~m})$ is not at fine enough resolution to overcome these issues. As such, a thorough knowledge of the study area is needed to minimise such issues. Furthermore, freshwater ecosystems are invaded by multiple plant invaders [80]. However, AIAPs observed in this study area (S. molesta, E. crassipes) generally form monocultures, and thus, the possibility to assign erroneous classification is relatively low. In addition to climate variability, several other factors, such as nutrient level, waves and water currents, and human influences, may contribute to the AIAPs distribution at various scales $[81,82]$. However, in this study, we did not consider other potential causes, as climate variability is considered as the most influential factor for plant invasions [72].

\section{Conclusions}

Freshwater aquatic systems are vulnerable to biological invaders under changing climate conditions. We conducted this research to examine how AIAPs' distribution responds to changes in climate variability in a selected TCS in Sri Lanka using ten historical time periods from 1992 to 2019. The findings revealed that the AIAPs infestation is increasing in the water systems over the long term, though there are shorter-term fluctuations. Based on the results of the Mann-Kendall test, Sen's slope estimator, and linear regression, we demonstrated positive trends in the annual average temperature and total rainfall in the study area. The output of the study shows a potential relationship between AIAPs and the changes in temperature, which could be highly important in understanding the future spatial and temporal distribution of AIAPs under climate change.

Author Contributions: Conceptualisation, C.S.K., L.K., B.K.K. and S.S.R.; methodology, C.S.K., L.K., B.K.K. and S.S.R.; software, C.S.K., B.K.K. and S.S.R.; validation, C.S.K., L.K., B.K.K. and S.S.R.; formal 
analysis, C.S.K.; investigation, C.S.K., B.K.K. and S.S.R.; resources, L.K.; data curation, C.S.K., B.K.K.; writing—original draft preparation, C.S.K.; writing—review and editing, C.S.K., L.K., B.K.K. and S.S.R.; visualisation, C.S.K., B.K.K. and S.S.R.; supervision, L.K. All authors have read and agreed to the published version of the manuscript.

Funding: This research received no external funding.

Data Availability Statement: Not applicable.

Acknowledgments: This study was completed as part of the $\mathrm{PhD}$ research programme for the Corresponding Author who wishes to thank the University of New England, NSW, Australia, for the Scholarship Award (UNE IPRA) in support of her studies.

Conflicts of Interest: The authors declare no conflict of interest.

\section{References}

1. Havel, J.E.; Kovalenko, K.E.; Thomaz, S.M.; Amalfitano, S.; Kats, L.B. Aquatic invasive species: Challenges for the future. Hydrobiologia 2015, 750, 147-170. [CrossRef]

2. Dudgeon, D.; Arthington, A.H.; Gessner, M.O.; Kawabata, Z.-I.; Knowler, D.J.; Lévêque, C.; Naiman, R.J.; Prieur-Richard, A.-H.; Soto, D.; Stiassny, M.L. Freshwater biodiversity: Importance, threats, status and conservation challenges. Biol. Rev. 2006, 81, 163-182. [CrossRef]

3. Millennium Ecosystem Assessment. Ecosystems and Human Well-Being: Synthesis; Island Press: Washington, DC, USA, 2005.

4. Abell, R. Conservation biology for the biodiversity crisis: A freshwater follow-up. Conserv. Biol. 2002, 16, 1435-1437. [CrossRef]

5. Secretariat of the Convention on Biological Diversity. Global Biodiversity Outlook 4; Secretariat of the Convention on Biological Diversity: Montréal, QC, Canada, 2014; p. 155.

6. Stiers, I.; Crohain, N.; Josens, G.; Triest, L. Impact of three aquatic invasive species on native plants and macroinvertebrates in temperate ponds. Biol. Invasions 2011, 13, 2715-2726. [CrossRef]

7. Gallardo, B.; Clavero, M.; Sánchez, M.I.; Vilà, M. Global ecological impacts of invasive species in aquatic ecosystems. Glob. Chang. Biol. 2016, 22, 151-163. [CrossRef]

8. Boylen, C.W.; Eichler, L.W.; Madsen, J.D. Loss of native aquatic plant species in a community dominated by Eurasian watermilfoil. Hydrobiologia 1999, 415, 207-211. [CrossRef]

9. McCormick, F.H.; Contreras, G.C.; Johnson, S.L. Effects of nonindigenous invasive species on water quality and quantity. A Dyn. Invasive Species Res. Vis. Oppor. Priorities 2009, 29, 111-120.

10. Mironga, J.M.; Mathooko, J.; Onywere, S. The effect of water hyacinth (Eichhornia crassipes) infestation on phytoplankton productivity in Lake Naivasha and the status of control. J. Environ. Sci. Eng. 2011, 5, 1252-1260.

11. Room, P.; Fernando, I. Weed invasions countered by biological control: Salvinia molesta and Eichhornia crassipes in Sri Lanka. Aquat. Bot. 1992, 42, 99-107. [CrossRef]

12. Villamagna, A.; Murphy, B. Ecological and socio-economic impacts of invasive water hyacinth (Eichhornia crassipes): A review. Freshw. Biol. 2010, 55, 282-298. [CrossRef]

13. Giller, P.S.; Hillebrand, H.; Berninger, U.G.; Gessner, O.M.; Hawkins, S.; Inchausti, P.; Inglis, C.; Leslie, H.; Malmqvist, B.; T. Monaghan, T.M. Biodiversity effects on ecosystem functioning: Emerging issues and their experimental test in aquatic environments. Oikos 2004, 104, 423-436. [CrossRef]

14. Tilman, D.; Lehman, C. Human-caused environmental change: Impacts on plant diversity and evolution. Proc. Natl. Acad. Sci. USA 2001, 98, 5433-5440. [CrossRef]

15. Holm, L.G.; Weldon, L.W.; Blackburn, R.D. Aquatic Weeds. Sci. New Ser. 1969, 166, 699-709. [CrossRef]

16. Weiss, J.; Dugdale, T. Part 2-Impacts of priority wetland weeds. In Knowledge Document of the Impact of Priority Wetland Weeds; Department of Environment, Land, Water and Planning (DELWP): Victoria, Australia, 2017; p. 81.

17. Holm, L.; Weldon, L.; Blackburn, R. Aquatic weeds. Science 1969, 166, 699-709. [CrossRef]

18. Cubasch, U.; Wuebbles, D.; Chen, D.; Facchini, M.C.; Frame, D.; Mahowald, N.; Winther, J.-G. Introduction. In Climate Change 2013: The Physical Science Basis. Contribution of Working Group I to the Fifth Assessment Report of the Intergovernmental Panel on Climate Change; Stocker, T.F., Qin, D., Plattner, G.-K.M., Tignor, S.K.A., Boschung, J., Nauels, A.Y., Xia, V.B., Midgley, P.M., Eds.; Cambridge University Press: Cambridge, UK; New York, NY, USA, 2013.

19. Rahel, F.J.; Olden, J.D. Assessing the effects of climate change on aquatic invasive species. Conserv. Biol. 2008, 22, 521-533. [CrossRef] [PubMed]

20. Bellard, C.; Jeschke, J.M.; Leroy, B.; Mace, G.M. Insights from modeling studies on how climate change affects invasive alien species geography. Ecol. Evol. 2018, 8, 5688-5700. [CrossRef] [PubMed]

21. Pratchett, M.S.; Bay, L.K.; Gehrke, P.C.; Koehn, J.D.; Osborne, K.; Pressey, R.L.; Sweatman, H.P.; Wachenfeld, D. Contribution of climate change to degradation and loss of critical fish habitats in Australian marine and freshwater environments. Mar. Freshw. Res. 2011, 62, 1062-1081. [CrossRef]

22. Burgmer, T.; Hillebrand, H.; Pfenninger, M. Effects of climate-driven temperature changes on the diversity of freshwater macroinvertebrates. Oecologia 2007, 151, 93-103. [CrossRef] 
23. Hellmann, J.J.; Byers, J.E.; Bierwagen, B.G.; Dukes, J.S. Five potential consequences of climate change for invasive species. Conserv. Biol. 2008, 22, 534-543. [CrossRef]

24. Kariyawasam, C.S.; Kumar, L.; Ratnayake, S.S. Invasive Plant Species Establishment and Range Dynamics in Sri Lanka under Climate Change. Entropy 2019, 21, 571. [CrossRef]

25. Jeschke, J.M.; Bacher, S.; Blackburn, T.M.; Dick, J.T.; Essl, F.; Evans, T.; Gaertner, M.; Hulme, P.E.; Kühn, I.; Mrugała, A. Defining the impact of non-native species. Conserv. Biol. 2014, 28, 1188-1194. [CrossRef]

26. Anderson, J.R. Land use and land cover changes. A framework for monitoring. J. Res. By Geol. Surv. 1977, 5, 143-153.

27. Leuven, R.; Boggero, A.; Bakker, E.S.; Elgin, A.K.; Verreycken, H. Invasive species in inland waters: From early detection to innovative management approaches. Aquat. Invasions 2017, 12, 269-273. [CrossRef]

28. Maldonado, M.; Maldonado-Ocampo, J.A.; Ortega, H.; Encalada, A.C.; Carvajal-Vallejos, F.M.; Rivadeneira, J.F.; Acosta, F.; Jacobsen, D.; Crespo, Á.; Rivera-Rondón, C.A. Biodiversity in Aquatic Systems of the Tropical Andes. Inter-American Institute for Global Change Research (IAI) and Scientific Committee on Problems of the Environment (SCOPE): 2011. 348. Available online: http:/ / www.iai.int (accessed on 4 December 2020).

29. Kariyawasam, C.S.; Kumar, L.; Ratnayake, S.S. Invasive Plants Distribution Modeling: A Tool for Tropical Biodiversity Conservation with Special Reference to Sri Lanka. Trop. Conserv. Sci. 2019, 12, 1-12. [CrossRef]

30. Cayuela, L.; Golicher, D.; Newton, A.; Kolb, M.; de Alburquerque, F.; Arets, E.; Alkemade, J.; Pérez, A. Species distribution modeling in the tropics: Problems, potentialities, and the role of biological data for effective species conservation. Trop. Conserv. Sci. 2009, 2, 319-352. [CrossRef]

31. Deb, P.; Tarafdar, S. Land Use Land Cover Change and Trend Analysis of Rainfall and Temperature Patterns in Mid-Himalayan Catchment Using Remote Sensing Data. In Advancement in Basic and Applied Sciences; Ancient Publishing House: Delhi, India, 2019.

32. Turner, W.; Rondinini, C.; Pettorelli, N.; Mora, B.; Leidner, A.K.; Szantoi, Z.; Buchanan, G.; Dech, S.; Dwyer, J.; Herold, M. Free and open-access satellite data are key to biodiversity conservation. Biol. Conserv. 2015, 182, 173-176. [CrossRef]

33. Kogo, B.K.; Kumar, L.; Koech, R. Analysis of spatio-temporal dynamics of land use and cover changes in Western Kenya. Geocarto Int. 2019, 1-16. [CrossRef]

34. Song, C.; Woodcock, C.E.; Seto, K.C.; Lenney, M.P.; Macomber, S.A. Classification and change detection using Landsat TM data: When and how to correct atmospheric effects? Remote Sens. Environ. 2001, 75, 230-244. [CrossRef]

35. Cohen, W.B.; Goward, S.N. Landsat's role in ecological applications of remote sensing. Bioscience 2004, 54, 535-545. [CrossRef]

36. Thomaz, S.M.; Kovalenko, K.E.; Havel, J.E.; Kats, L.B. Aquatic invasive species: General trends in the literature and introduction to the special issue. Hydrobiologia 2015, 746, 1-12. [CrossRef]

37. Sala, O.E. Global Biodiversity Scenarios for the Year 2100. Science 2000, 287, 1770-1774. [CrossRef] [PubMed]

38. Bebermeier, W.; Meister, J.; Withanachchi, C.R.; Middelhaufe, I.; Schütt, B. Tank cascade systems as a sustainable measure of watershed management in South Asia. Water 2017, 9, 231. [CrossRef]

39. Dharmasena, P.B. Water balance of a tank cascade system in the dry zone. In Proceedings of the 54th Annual Session of SLAAS, Colombo, Sri Lanka, 14-19 December 1998.

40. Madduma Bandara, C.M. Catchment ecosystems and village TankCascades in the dry zone of Sri Lanka a time-tested system of land and water resource management. In Strategies for River Basin Management; Springer: Dordrecht, The Netherlands, 1985; pp. 99-113.

41. MMD\&E. Invasive Alien Species in Sri Lanka: Training Manual for Managers and Policymakers; Biodiversity Secretariat, Ministry of Mahaweli Development \& Environment: Colombo, Sri Lanka, 2015.

42. Room, P.; Gunatilaka, G.; Shivanathan, P.; Fernando, I. Control of Salvinia molesta in Sri Lanka by Cyrtobagous salviniae. In Proceedings of the VII International Symposium on Biological Control of Weeds, Rome, Italy, 6-11 March 1988.

43. Jensen, J.R. Introductory Digital Image Processing: A Remote Sensing Perspective, 3rd ed.; Prentice-Hall: Upper Saddle River, NJ, USA, 2005.

44. Lu, D.; Mausel, P.; Brondizio, E.; Moran, E. Change detection techniques. Int. J. Remote Sens. 2004, 25, 2365-2401. [CrossRef]

45. Phiri, D.; Morgenroth, J. Developments in Landsat land cover classification methods: A review. Remote Sens. 2017, 9, 967. [CrossRef]

46. Sonka, M.; Hlavac, V.; Boyle, R. Image pre-processing. In Image Processing, Analysis and Machine Vision; Springer: Boston, MA, USA, 1993.

47. Young, N.E.; Anderson, R.S.; Chignell, S.M.; Vorster, A.G.; Lawrence, R.; Evangelista, P.H. A survival guide to Landsat preprocessing. Ecology 2017, 98, 920-932. [CrossRef]

48. Padró, J.-C.; Muñoz, F.-J.; Ávila, L.Á.; Pesquer, L.; Pons, X. Radiometric correction of Landsat-8 and Sentinel-2A scenes using drone imagery in synergy with field spectroradiometry. Remote Sens. 2018, 10, 1687. [CrossRef]

49. Gilmore, S.; Saleem, A.; Dewan, A. Effectiveness of DOS (Dark-Object Subtraction) method and water index techniques to map wetlands in a rapidly urbanising megacity with Landsat 8 data. In Proceedings of the Research@Locate '15 2015, Brisbane, Australia, 10-12 March 2015; pp. 100-108. Available online: https://espace.curtin.edu.au/handle/20.500.11937/43918 (accessed on 6 November 2020).

50. Vanjare, A.; Omkar, S.; Senthilnath, J. Satellite Image Processing for Land Use and Land Cover Mapping. Int. J. Image Graph Signal Process 2014, 6, 18. [CrossRef] 
51. Ko, B.C.; Kim, H.H.; Nam, J.Y. Classification of potential water bodies using Landsat 8 OLI and a combination of two boosted random forest classifiers. Sensors 2015, 15, 13763-13777. [CrossRef]

52. Haque, M.I.; Basak, R. Land cover change detection using GIS and remote sensing techniques: A spatio-temporal study on Tanguar Haor, Sunamganj, Bangladesh. Egypt. J. Remote Sens. Space Sci. 2017, 20, 251-263. [CrossRef]

53. Ismail, M.H.; Jusoff, K. Satellite data classification accuracy assessment based from reference dataset. Int. J. Comput. Inf. Sci. Eng. 2008, 2, 96-102.

54. Owojori, A.; Xie, H. Landsat image-based LULC changes of San Antonio, Texas using advanced atmospheric correction and object-oriented image analysis approaches. In Proceedings of the 5th International Symposium on Remote Sensing of Urban Areas, Tempe, AZ, USA, 14-16 March 2005.

55. Fitzgerald, R.; Lees, B. Assessing the classification accuracy of multisource remote sensing data. Remote Sens. Environ. 1994, 47, 362-368. [CrossRef]

56. Mann, H.B. Nonparametric tests against trend. J. Econom. Soc. 1945, 245-259. [CrossRef]

57. Kendall, M.G. Rank Correlation Methods; Griffin: London, UK, 1975.

58. Sen, P.K. Estimates of the regression coefficient based on Kendall's tau. J. Am. Stat. Assoc. 1968, 63, 1379-1389. [CrossRef]

59. Tadese, M.T.; Kumar, L.; Koech, R.; Zemadim, B. Hydro-Climatic Variability: A Characterisation and Trend Study of the Awash River Basin, Ethiopia. Hydrology 2019, 6, 35. [CrossRef]

60. Gocic, M.; Trajkovic, S. Analysis of changes in meteorological variables using Mann-Kendall and Sen's slope estimator statistical tests in Serbia. Glob. Planet. Chang. 2013, 100, 172-182. [CrossRef]

61. Lea, C.; Curtis, A.C. Thematic Accuracy Assessment Procedures: National Park Service Vegetation Inventory, Version 2.0. Natural Resource Report NPS/2010/NRR—2010/204; National Park Service: Fort Collins, CO, USA, 2010.

62. Mahmood, R.; Jia, S.; Zhu, W. Analysis of climate variability, trends, and prediction in the most active parts of the Lake Chad basin, Africa. Sci. Rep. 2019, 9, 6317. [CrossRef]

63. IPCC (Intergovernmental Panel on Climate Change). Climate Change 2007: The Physical Science Basis: Summary for Policymakers. Contribution of Working Group I to the Fourth Assessment Report of the Intergovernmental Panel on Climate Change; IPCC: Geneva, Switzerland, 2007.

64. Thomas, R.; Kane, A.; Environmental Law Institute; Bierwagen, B.G. Effects of Climate Change for Aquatic Invasive Species and Implications for Management and Research; U.S. Environmental Protection Agency: Washington, DC, USA, 2008. Available online: https:/ / digitalcommons.unl.edu/usepapapers/51/ (accessed on 20 December 2020).

65. Stephens, K.L.; Dantzler-Kyer, M.E.; Patten, M.A.; Souza, L. Differential responses to global change of aquatic and terrestrial invasive species: Evidences from a meta-analysis. Ecosphere 2019, 10, e02680. [CrossRef]

66. Chen, D.-X.; Coughenour, M.; Eberts, D.; Thullen, J.S. Interactive effects of CO2 enrichment and temperature on the growth of dioecious Hydrilla verticillata. Environ. Exp. Bot. 1994, 34, 345-353. [CrossRef]

67. Idso, S.; Kimball, B.; Anderson, M.; Mauney, J. Effects of atmospheric CO2 enrichment on plant growth: The interactive role of air temperature. Agric. Ecosyst. Environ. 1987, 20, 1-10. [CrossRef]

68. Ojala, A.; Kankaala, P.; Tulonen, T. Growth response of Equisetum fluviatile to elevated CO2 and temperature. Environ. Exp. Bot. 2002, 47, 157-171. [CrossRef]

69. Tulloss, E.M.; Cadenasso, M.L. The effect of nitrogen deposition on plant performance and community structure: Is it life stage specific? PLoS ONE 2016, 11, e0156685. [CrossRef]

70. Mahatantila, K.; Chandrajith, R.; Jayasena, H.; Ranawana, K. Spatial and temporal changes of hydrogeochemistry in ancient tank cascade systems in Sri Lanka: Evidence for a constructed wetland. Water Environ. J. 2008, 22, 17-24. [CrossRef]

71. IPCC. Climate Change 2014: Synthesis Report. Contribution of Working Groups I, II and III to the Fifth Assessment Report of the Intergovernmental Panel on Climate Change; IPCC: Geneva, Switzerland, 2014.

72. Woodward, F.I. Climate and Plant Distribution; Cambridge University Press: New York, NY, USA, 1987.

73. Liu, X.; Guo, Z.; Ke, Z.; Wang, S.; Li, Y. Increasing potential risk of a global aquatic invader in Europe in contrast to other continents under future climate change. PLoS ONE 2011, 6, e18429. [CrossRef]

74. Peterson, A.T.; Stewart, A.; Mohamed, K.I.; Araújo, M.B. Shifting global invasive potential of European plants with climate change. PLoS ONE 2008, 3, e2441. [CrossRef]

75. Ghosh, M.K.; Kumar, L.; Roy, C. Climate variability and mangrove cover dynamics at species level in the Sundarbans, Bangladesh Sustainability 2017, 9, 805. [CrossRef]

76. Adepoju, K.; Adelabu, S.; Fashae, O. Vegetation Response to Recent Trends in Climate and Landuse Dynamics in a Typical Humid and Dry Tropical Region under Global Change. Adv. Meteorol. 2019, 2019. [CrossRef]

77. Gillard, M.; Thiébaut, G.; Deleu, C.; Leroy, B. Present and future distribution of three aquatic plants taxa across the world: Decrease in native and increase in invasive ranges. Biol. Invasions 2017, 19, 2159-2170. [CrossRef]

78. Arp, R.; Fraser, G.; Hill, M. Quantifying the economic water savings benefit of water hyacinth (Eichhornia crassipes) control in the Vaalharts Irrigation Scheme. Water SA 2017, 43, 58-66. [CrossRef]

79. Foody, G. Monitoring the magnitude of land-cover change around the southern limits of the Sahara. Photogramm. Eng. Remote Sens. 2001, 67, 841-848.

80. Mills, E.L.; Leach, J.H.; Carlton, J.T.; Secor, C.L. Exotic species in the Great Lakes: A history of biotic crises and anthropogenic introductions. J. Great Lakes Res. 1993, 19, 1-54. [CrossRef] 
81. Rai, P.K.; Singh, J. Invasive alien plant species: Their impact on environment, ecosystem services and human health. Ecol. Indic. 2020, 111, 106020.

82. Parepa, M.; Fischer, M.; Bossdorf, O. Environmental variability promotes plant invasion. Nat. Commun. 2013, 4, 1604. [CrossRef] [PubMed] 